\title{
Gypsum Supplies Calcium to Ultisol Soil and Its Effect on Pineapple Growth, Yield and Fruit Quality in Lower Single Bed under Climate Change Issue
}

\author{
Supriyono Loekito ${ }^{1}$ Afandi2 ${ }^{*}$, Auliana Afandi ${ }^{3}$, Naomasa Nishimura ${ }^{4}$, Hiroyuki Koyama ${ }^{4}$, and Masateru Senge ${ }^{5}$ \\ 1 Research and Development, PT Great Giant Pineapple,Jl. Raya Terbanggi Km 77,Central Lampung,Lam- \\ pung Indonesia, 34163 \\ 2 Department of Soil Science, Faculty of Agriculture, Lampung University, Jl. Sumantri Brojonegoro 1, Ban- \\ dar Lampung, Lampung, Indonesia 35145 \\ 3 Department of Plant Protection, Faculty of Agriculture, Lampung University, Jl. Sumantri Brojonegoro 1, \\ Bandar Lampung, Lampung, Indonesia 35145 \\ 4 Faculty of Applied Biological Science, Gifu University, 1-1 Yanagido, Gifu, Japan \\ 5 Gifu University Laboratory, Ltd. Union, 1-1 Yanagido, Gifu, Japan \\ * Corresponding author: afandi.unila@gmail.com; supriyono.loekito@ggpc.co.id
}

\begin{abstract}
A lower bed single row for pineapple cultivation could protect pineapple from soil erosion in rainy season and during drought, however, disease problem could arise due to water logging. Two experiments using a lower bed single row was done to understand the ability of gypsum providing soil calcium $(\mathrm{Ca})$ available to pineapple plant, resistance to heart rot disease, and give better effect on crop growth and fruit quality of the pineapple in Ultisol soil. In the first trial, four level dosis of gypsum $\left(0,1.0,1.5,2.0 \mathrm{Mg} \mathrm{ha}^{-1}\right)$ and dolomite $2 \mathrm{Mg}^{-1} \mathrm{a}^{-1}$ were applied by spreading and incorporated into the soil which have saturated with inoculums of Phytophthora nicotianae. In the second trial, gypsum treatments $\left(0,1.0,1.5,2.0,2.5 \mathrm{Mg} \mathrm{ha}^{-1}\right)$ were applied in the row between the single row beds as a basic fertilizer. The result showed that $P$. nicotianae attacked the pineapple plants in all treatments at 6 weeks after planting (WAP), and at 10 WAP, the mortality of dolomite treatment reached $63.8 \%$, significantly different than that for gypsum treatments (3.3-14.3\%). In the second experiment, gypsum increased plant weight significantly at 3 until 9 months after planting especially when it was applied $1.5-2.5 \mathrm{Mg} \mathrm{ha}^{-1}$. Fruit texture, total soluble solid (TSS), titratable acidity (TA) were not significant different among the treatment but all meet the standards for grades of canned pineapple. Result showed that soil applied gypsum before planting provides soil calcium and met the plant Ca requirement during a period of early and fast growth step and safe for heart rot disease.
\end{abstract}

Keywords: Lower bed single row; plant weight; fruit texture; crop growth

\section{Introduction}

Pineapple is one of the economically most important tropical fruit a worldwide scale. At current time, PT Great Giant Pineapple (GGP) plantation in Lampung, Sumatera, is now the biggest single pineapple plantation in the world. The climate is humid tropical where the annual rainfall, average temperature, relative humidity, duration of sunshine and standard evaporation rate are 2,500 mm/year, 21 to $33^{\circ} \mathrm{C}, 83 \%, 4.6$ hours/day and 36 $\mathrm{mm} /$ day, respectively. The year-round temperatures, heavy rainfall, and high humidity 
are unique to the humid tropics and cause the organic material in the soil to decompose at a high rate, resulting in low chemical fertility, a high clay content, and low soil pH. The soil is generally categorized as Red-Yellow Podzolic or Ultisol soil [1]. This soil covers a large part of Indonesia's land surface, approximately 45,794,000 ha (25\%) and about $21 \%$ of that land $(9,469,000 \mathrm{ha})$ is on Sumatera Island [2].

During the last 10 years, the unpredictable rainfall made the pineapple cultivation had faced several problems, especially with long dry season. "Wet dry season", where the amount of rainfall occurred during dry season almost the same with rainy season occurred 5 times for the last 10 years from 2010-2020, while long dry season occurred 4 times (Fig. 1). High rainfall, soil erosion, low soil fertility, and soil borne disease are the challenges in pineapple cultivation in these conditions. Commonly pineapple was planted in a raise bed double row (Fig. 2), erosion problem usually come when the rainfall was high which caused in damaged beds shape and disturbed roots and plant during pineapple growth, while it is also susceptible to drying condition and water logging. A pineapple's cultivation in lower bed single row was used in this research so the roots were not disturbed, stronger with challenge of soil borne disease due to poorer drainage, and more resistance to drying compare to raised bed.

In addition to uncertain climate condition lately, the second biggest problem in pineapple under humid tropical climate was the availability of calcium (Ca) in the soil. To manage 32,000 ha area of GGP plantation, the field was divided into blocks, 10 to 15 ha each. When the cultivation of pineapple began in 1986, the soil Ca content in all blocks of the plantation was higher (206 to $434 \mathrm{mg} / \mathrm{kg}$ ) than the standard soil Ca adequate, which is 100 $\mathrm{mg} / \mathrm{kg}$ [3]. However, in 1993, the blocks with a soil Ca content greater than the standard had decreased to $90 \%$, and in 2004, only $60 \%$ of the blocks met that standard. The soil pH values of the GGP plantation range from 3.7-5.9, whereas the optimum soil pH for cultivated pineapple ranges from 4.7-5.5 [4].

Calcium (Ca) is an essential crop nutrient and the primary cation used to manage soil $\mathrm{pH}$. It is required for synthesis of new cell wall, especially the middle lamellae that separate the new cell during cell division, and for the normal function of the plant membranes [5]. Calcium also plays an important role in nutrient balances in plant and soil [6]. Many physiological disorders of fruits and vegetables are related to Ca [7]. In humid tropical climate which soil generally dominated by red acid soil (Ultisol), the deficiency of Ca was occurred low due to the low $\mathrm{pH}$ and low cation exchange capacity (CEC) of the soil [8]. However, in pineapple cultivation, increasing soil $\mathrm{pH}$ above 5 would promote disease in the form of heart rot and root rot disease due to Phytophthora sp. [9,10,11]. On the other hand, if the $\mathrm{pH}$ is very low, the availability of macro nutrient will be limited.

Soil with Ca content below $25 \mathrm{mg} / \mathrm{kg}$ can induce calcium deficiency symptoms in the pineapple plant and fruit [3]. The symptoms of calcium deficiency are necrosis of the edges of the rapidly growing young leaves and multiple small and sometimes deformed fruits [12]. Dolomite lime is commonly applied to the fields to raise the soil $\mathrm{pH}$ to at least 4.7 as well as to supply $\mathrm{Ca}$ and $\mathrm{Mg}$. Alternative of dolomite to supplied Ca when the soil $\mathrm{pH}$ was quite high is gypsum. Large amounts of gypsum will not increase the soil pH [13]. Pegg and Giblin [14] reported that gypsum supplied Ca, increased the disease resistance 
of avocado roots and acted as a mild fungicide by suppressing the formation of Phytophthora spores. Messenger et al. (2000) [15] showed that zoospore production of Phytophthora cinnamomi in avocados was decreased by $78 \%$ in soil that had been treated with $1 \%$ gypsum and that the number of zoospores was decreased by $74 \%$ with a $5 \%$ gypsum treatment. Correia et al. (2017) [16] reported that soil management with millet coverage and gypsum let to adequate levels of nutrients in the soil at the end of the pineapple crop cycle.

The objective of the present research was to evaluate gypsum as a substitute of dolomite in supplying calcium in the pineapple plant and soil and to know the effects of soil application Ca gypsum on the root system, crop growth, fruit quality and Phytophthora cinnamomi disease incidence of pineapple cultivated in Ultisol soil under single lowered bed system. By this present experiment result, Ca needs to soil and plant could be supplied to meet the requirement standard without any problem of the disease, the Integrated Disease Management in humid tropical could be improved to keep the sustainable pineapple production.

\section{Materials and Methods}

Two field experiments were conducted at the research station in a pineapple field of GGP plantation, with latitude $04^{\circ} 49^{\prime} 13^{\prime \prime}$ South and longitude $105^{\circ} 13^{\prime} 13^{\prime \prime}$ East, during 2016 - 2018.

Experiment I: Effect of gypsum soil application on hearth rot disease (Phytophthora nicotianae.)

The experimental design was a randomized complete block design with five treatments and three replications. The experimental plots were prepared in an area known to be infested with Phytophthora spp previously before September 2016. The soil in the experimental plots was saturated with inoculums of fungi that have identified as Phytophthora nicotianae [17] by watering the soil with a solution prepared by soaking infected plants. Then treatments were applied and the soil was tilled to evenly incorporate the liming treatment. The gypsum $(G)$ treatments and dolomite $(D)$ in ton ha-1 of amendment and kg ha-1 Ca, were G0 (untreated), G1 (1.0 and 233), G2 (1.5 and 349), G3 (2.0 and 465), and D1 (2.0 and 440). The gypsum was spread and incorporated into the soil a week before planting on December, 2016. The dolomite treatment was spread and incorporated into the soil during land preparation in the plots two months before planting on October, 2016.

Each plot contained at least 200 plants in 10 single row beds spaced $55 \mathrm{~cm}$ apart with $27 \mathrm{~cm}$ between plants in the row (equivalent to 67340 plants ha- $^{-1}$ ). There were four border rows between the plots to avoid unwanted interaction and the plots were planted and maintained following conventional plantation practices. Magnesium sulfate monohydrate $\left(\mathrm{MgSO}_{4} \mathrm{H}_{2} \mathrm{O}\right)$ at $100 \mathrm{~kg} \mathrm{ha}^{-1}$ was applied in the soil as a basic fertilizer together with diammonium phosphate (DAP) and potassium chloride $(\mathrm{KCl})$ before planting. Selected medium size crowns of 'Smooth Cayenne' clone GP3 (250 - $350 \mathrm{~g}$ in weight) were planted on December, 2016. 
Data on plant mortality caused by Phytophthora nicotianae were collected from each plot by counting the dead plants 4, 6, 8 and 10 weeks after planting (WAP). The percent of plant mortality (disease incidence) was calculated by the following formula:

$$
\text { Plant mortality }=\frac{\text { Numbers of died plants }}{\text { Total numbers of plants }} \times 100 \%
$$

The soil $\mathrm{pH}\left(\mathrm{H}_{2} \mathrm{O}\right)$ was measured by $\mathrm{pH}$ meter - Mettler Toledo at 0 (before the treatments were applied), 4 and 10 weeks after planting. The Ca and $\mathrm{Mg}$ in the soil were extracted with neutralized $1 \mathrm{~N}$ acetic acid at $\mathrm{pH} 7$ and analyzed by atomic absorption spectrophotometry (AAS).

Experiment II: Effect of gypsum soil application on soil and leaf nutrition, plant response and fruit quality

The experimental design was a randomized complete block design with six treatments and four replications. Soil gypsum treatments were applied in the row between the single bed as a basic fertilizer before planting together with $\mathrm{KCl}\left(200 \mathrm{~kg} \mathrm{ha}^{-1}\right)$, DAP (250 kg ha-1), MgSO4.H2O (300 kg ha-1), $\mathrm{CuSO}_{4}\left(10 \mathrm{~kg} \mathrm{ha}^{-1}\right)$, Borax (10 kg ha-1) and Fine Compost (4.0 ton ha-1). The gypsum (G) treatment in ton ha-1 and $\mathrm{kg} \mathrm{ha}^{-1} \mathrm{Ca}$ were G0 (Untreated and 0), G1 (0.5 and 116), G2 (1.0 and 233), G3 (1.5 and 349), G4 (2.0 and 465), and G5 (2.5 and 440). Soil $\mathrm{pH}$ at the beginning was 4.2 , and then $1000 \mathrm{~kg} \mathrm{ha}^{-1}$ of Dolomite lime was applied on June, 2016. Soil pH increase reached to 4.4 at planting on September, 2016 (Table 1).

Soil properties ( $\mathrm{pH}, \mathrm{P}, \mathrm{K}, \mathrm{Ca}, \mathrm{Mg}, \mathrm{Cu}$, total $\mathrm{C}$, total $\mathrm{N}$ ) was observed at initial and at planting. Calcium and magnesium content in the soil and leaf were observed at 2, 3, 6, 7 and 9 months after planting (MAP). The length of the longest leaf with a leaf angle of $45^{\circ}$ from the soil surface (D-leaf) and plant weight were measured destructively at 3, 7, 9 and 11 MAP. Root length, total number, fresh weight and dry weight were observed at 3 MAP obtained. Plant weight, stem weight, fruit weight, crown weight, fruit size and crown size distribution were observed at harvest. Fruit quality of total soluble solid (TSS), titratable acidity (TA), TSS/TA ratio and fruit texture were observed at harvest.

The following soil nutrients were analyzed using the following methods: (a) $\mathrm{pH}$ with pH meter - Mettler Toledo, (b) C organic with Walkey and Black method, (c) P with P Bray method, (d) K, Ca and Mg were analysed using extraction by acetic acid pH 7 and reading with AAS, (e) micro nutrient $(\mathrm{Cu})$ was analyzed using extraction by DTPA and reading with AAS, (f) $\mathrm{N}$ with Kjeldahl methods. Leaf analysis was done on D-leaf. One third of the upper leaves sample were cut not used, and the leaves were cut into pieces and separated into two parts; on part which green color were used for micro nutrient analysis and other part which have white/ pale color were used for macro nutrient analysis, and then dried in oven with temperature $70^{\circ} \mathrm{C}$ for 24 hours. The dry leaf samples were grinded and sieve with $0.5 \mathrm{~mm}$. Extraction was done using $\mathrm{HNO}_{3}$ and $\mathrm{H}_{2} \mathrm{O}_{2}$ and destruction was done in temperature $175^{\circ} \mathrm{C}$. The AAS was used for reading macro and micronutrient, except P using spectrometer.

D-leaf was collected from each treatment plot. D-leaf is easily identified on the pineapple plant because it is the longest leaf with a leaf angle of $45^{\circ}$ from the soil surface. 
The D-leaf length is measured from the bottom to the top using ruler. The root samples were taken by circling each plant with a steel ring $54.5 \mathrm{~cm}$ in diameter, and $25 \mathrm{~cm}$ in height, then watering the soil carefully to separate the soil and the rhizosphere. The length of the longest root from the stem was measured with a ruler. The number of roots from the stem was counted. To get the fresh and dry root weight the roots were cut from the basal stem, air dried at room temperature to remove excess moisture and then weighed to determine fresh weight. Roots were then oven dried to a constant weight at $105^{\circ} \mathrm{C}$ to obtain the dry weight data.

To determine TSS content the fruit flesh sample was cut into small pieces (not including the fruit skin, fruit core or the top and bottom $2 \mathrm{~cm}$ of the fruit) then the juice was extracted, filtrate was measured by a hand-held refractometer (MASTER-53 $\alpha$; Atago, Japan). TA was detected by titration to $\mathrm{pH} 8.1$ with $0.1 \mathrm{M} \mathrm{NaOH}$ using phenolphthalein as an indicator and revealed as a percentage of citric acid. Fruit texture was measured at three point regions of the fruit slices taken from the top, middle and bottom section using a Brookfield Ametex CT3 Texture Analyser, a compression and tension testing tool for rapid quality control analyses. The fixture used was TA5 (a cylindrical probe $12.7 \mathrm{~mm}$ in diameter and $35 \mathrm{~mm}$ in length). Fruit size distribution was made by measured the larger diameter of the pineapple fruit: (a) $<1 \mathrm{~T}$ diameter $<9.9 \mathrm{~cm}$, (b) $1 \mathrm{~T}$ diameter $9.9-10.5 \mathrm{~cm}$, (c) $13 / 8 \mathrm{~T}$ diameter $10.6-11.5 \mathrm{~cm}$, (d) $2 \mathrm{~T}$ diameter $11.6-12.9 \mathrm{~cm}$, (e) $21 / 2 \mathrm{~T}$ diameter $>12.9$ $\mathrm{cm}$. Crown size distribution was made by measured the crown weight: (a) Extra small is < $150 \mathrm{~g}$, (b) Small is $150-200 \mathrm{~g}$, (c) Medium is $201-350 \mathrm{~g}$, (d) Big is $351-450 \mathrm{~g}$, and (e) Extra big is $>450 \mathrm{~g}$. The collected data were analysed using an analysis of variance (ANOVA), and the means were compared with the Tukey test with a difference of $95 \%(P<0.05)$.

\section{Results}

Effect of gypsum soil application on hearth rot disease (Phytophthora nicotianae) incidence

The result showed that there was higher plant mortality in the D treatment than in the $G$ treatments (Table 2). The shortest period from planting until significant numbers of plants had disease symptoms was four weeks after planting for treatment D1 (Table 2). Treatment D1 had also the highest soil $\mathrm{pH}$ among the treatments (Table 3). Eight weeks after planting, the plant mortality remained $54.3 \%$ significantly higher for treatment D1 than for all other treatments, while the plant mortality for the G treatments was variable, but the differences were not significant (Table 2).

Effect of gypsum soil application on soil and leaf nutritions, plant response and fruit quality

The soil calcium content was affected by gypsum application consistently until 6 month after planting and declined by the time (Fig. 4). As shown in Fig. 5, untreated had a lower Ca uptake to the leaves compare to all gypsum treatments.

The effect of gypsum soil application on plant growth was provided in Table 4, while for root response was presented in Table 5. The application did not give any statistical difference to untreated on the D-Leaf length at 3, 7,9 and $11 \mathrm{MAP}$, but increased plant weight significantly at 3 until 9 map. Root length, total root number, root fresh and dry weight were not affected significantly different by gypsum application. 
Fruit weight, crown weight, stem weight and plant weight at harvest showed higher in all dosage treatments of gypsum compare to untreated but did not significant different (Table 6). Fruit TSS, TA, TSS/TA ratio and fruit texture (firmness) were presented in Table 7. There were not significant different of TSS, TA and fruit texture among treatments, but all gypsum treatment showed higher firmness value than untreated both in shell colour 1 and 3. Fruit size and crown size distribution at harvest were presented in Table 8, 9. All of Ca gypsum treatments could increase the number of big fruit size $2 \mathrm{~T}$ and $2 \frac{1}{2} \mathrm{~T}$.

\section{Discussion}

The goals of the current experiment was the evaluation of an effect of gypsum soil application on hearth rot disease (Phytophthora nicotianae) incidence and the effect on soil and leaf nutrition, plant response and pineapple fruit quality. The results showed that $P$. nicotianae attacked the pineapple plants in all treatments six weeks after planting when the soil pH was over 5.0 due to high rainfall from December 2016 to March 2017, namely 270, 369, 352 and $418 \mathrm{~mm}$ per month, respectively. The mortality rates continued to increase with the increasing soil $\mathrm{pH}$. Ten weeks after planting, the mortality with treatment $\mathrm{D} 1$ reached $63.8 \%$ when the soil $\mathrm{pH}$ was 5.9 . This is significantly different than that for the $\mathrm{G}$ treatment (3.3-14.3\%) with a soil $\mathrm{pH}$ level of 4.5-4.7.

Increasing the amounts of gypsum did not consistently increase the soil pH (Table 2). Ten weeks after planting, the plant mortality was low for treatments G0 through G3 and significantly different than treatment D1. This shows that keeping the soil pH low (treatment G0) and adding Ca using gypsum (treatment G1-G3) are more beneficial than using dolomite (treatment D1). Tsao et al. (1986) [18] reported that soil amendment with gypsum (calcium sulfate monohydrate) showed inhibition activity agains sporangium formation of $P$. parasitica that could not be done by lime, hydrate lime or dolomite lime. Calcium ion may stimulate a compound known to be implicated in the defense mechanisms of plants, called phytoalexin, as a result of fungal attacks [19].

The results also showed that the soil Ca contents in treatments G2 and G3 were significantly higher than that of the untreated soil ten weeks after planting (Table 2). Gypsum is moderately soluble in water $(2.5 \mathrm{~g} / \mathrm{l})$ or approximately 200 times greater than lime [20]. This makes the Ca in gypsum more mobile than the Ca in dolomite lime and allows it to more easily move through the soil profile. When the initial soil content of $\mathrm{Mg}$ is less than $50 \mathrm{mg} / \mathrm{kg}$ a magnesium application is required [21]. In the present experiment the initial $\mathrm{Mg}$ content was $99 \mathrm{mg} / \mathrm{kg}$ and kieserite fertilizer (magnesium sulfate monohydrate: $\mathrm{MgSO}_{4} \cdot \mathrm{H}_{2} 0$ ) was applied at planting time together with $\mathrm{DAP}$ and $\mathrm{KCl}$ to keep the $\mathrm{Mg}$ content at not less than $50 \mathrm{mg} / \mathrm{kg}$ in the soil. Nontheless the Mg content in the soil increased to $162 \mathrm{mg} / \mathrm{kg}$ in eight months and decreased to $159 \mathrm{mg} / \mathrm{kg}$ with D1 higher than all $\mathrm{G}$ treatments ten weeks after the pineapples were maintained with GGP's fertilizer regime. According to Nome et al. (2009) [22] magnesium can actually suppress Phytophthora by influencing how the pathogens invade and colonize plant tissue. When the 
$\mathrm{Mg}$ nutrient is sufficient during plant growth the structural integrity of the middle lamella and the production of energy necessary for defense functions and inactivation of pathogen metabolites will increase [23]. Tsao et al. (1986) [18] reported that $\mathrm{Mg}$ ion induces the sporangia of $P$. parasitica to become nonfunctional or prevents the release of zoospores. Magnesium content in the soil was highest in treatment D1 but the highest mortality was seen also in the D1 treatment. It appears that higher soil pH level has a greater effect on increasing the disease than $\mathrm{Mg}$ ability to suppress the disease.

Calcium increases the absorption of some nutrients, such as ammonium, potassium and phosphorus, stimulates photosynthesis, and increases the size of the sellable plant parts [24]. Soil application of gypsum dosage 1.0-2.5 ton/ha could maintain the soil Ca content remain above the standard. Meanwhile, if Ca was supplied only by dolomite application at liming, it must be re-applied to meet the standard requirement not less than $100 \mathrm{mg} / \mathrm{kg}$ (Fig. 4). The higher the dose of gypsum applied to the soil, the higher $\mathrm{Ca}$ uptake to the leaves (Fig. 5).

Calcium is used in the synthesis of new cell walls, particularly the synthesis of the middle lamella to separate the newly divided cells [24]. The D-Leaf had 'succulent-brittle' leaf base that are commonly used to evaluate the plant nutrient status as an index of growth [25]. In this experiment, it was shown that soil applied calcium gypsum application as a basic fertilizer have no effect significantly on D-Leaf length. Calcium gypsum also increased plant weight significantly at 3 until 9 MAP when applied with high level dose 1.5-2.5 ton/ha (Table 4). Actually, the stem weight increases progressively after planting, with no unique morphological changes in the plant until the reproductive development phase begins [3]. Calcium can be supplied at high concentrations more than $10 \%$ of the dry weight in mature leaves without symptoms of toxicity or serious inhibition of plant growth [26].

The case also similar with the root system; root length, root number, root fresh and dry weight were not affected by gypsum application at 3 months after planting (Table 5). The roots of the pineapple plant may grow continuously throughout the year, but there is evidence that the root growth decreases after the flower induction and that the maximum root mass is reached at anthesis (Malezieux and Bartholomew, 2003). Actually, the availability of Ca in the rhizosphere supports the elongation of the root cells [27]. However, the proliferation depends on the availability of water and minerals in the rhizosphere. If the rhizosphere is too dry or poor in nutrients, the root growth is slow. The root growth increases when the condition of the rhizosphere improves [24]. Excess or lack of moisture, high salinity, roots disease are conditions that restrict the $\mathrm{Ca}$ uptake, may lead Ca deficiency symptoms in plant [28].

Fruit size, crown size and fruit quality usually depend on type, environment and cultivations. Fruit weight, crown weight, plant weight and stem weight at harvest were affected by calcium gypsum and increased compare to untreated regardless of the dose given in the treatments although did not statistically significant (Table 6). The fruit quality in the most fruit is determined by sugar content [29]. In this study, fruit quality (physio-chemical) analysis were made with following parameters of TSS, TA, TSS/TA (brix acid) ratio and fruit firmness. The result showed that TSS, TA and TSS/TA ratio 
were not significant different among the treatment (Table 7) but all meets standard of United States Standards for Grades of Canned Pineapple [30] and also meet requirement for fresh fruit market in Hawaii and Australia which a minimum of 12 Brix soluble solids content in the fruit [31], while the TSS level of all treatments were in range of 12.0-13.5 oBrix. The TSS activity in all fruits increased during ripening progress.

When more soluble calcium is available in the soil, the calcium uptake into the pineapple fruit and the firmness of the flesh will increase. To evaluate the effect of calcium gypsum on the fruit firmness, the result were made in two stages of fruit ripening SC1 (shell colour 1, 10\% yellow) and SC3 (shell colour 3, 20-30\% yellow). All gypsum treatments increase the firmness both in SC1 and SC3, It showed need more energy (gram force) to pressure the pineapple flesh to changing shape or anthesis in treated soil than in untreated soil although not significantly different both in top, middle and bottom part of the fruit (Table 7). Previous research reported that a high level of calcium could prevent the deterioration of the cell wall pectate and that it was important to maintain the integrity of the cell membrane and the cell wall stabilization [26].

\section{Conclusions}

The plant mortality of dolomite treatment reached $63.8 \%$ when the soil pH was 5.9, higher than the gypsum treatments (3.3-14.3\%) with a soil $\mathrm{pH}$ level of $4.5-4.7$ at ten months after planting. Soil application of gypsum dose 1.0-2.5 ton/ha could maintain the soil Ca content remain above the standard value of $100 \mathrm{mg} / \mathrm{kg}$ for more than $7 \mathrm{MAP}$, increased $\mathrm{Ca}$ and $\mathrm{K}$ uptake to the leaves, but was not for $\mathrm{Mg}$ and P. Calcium gypsum also increased plant weight significantly at 3 until 9 MAP when applied with high level dose 1.5-2.5 ton/ha. Soil applied gypsum before planting met the plant Ca and $\mathrm{Mg}$ requirement during a period of early and fast growth step and recommended to be used as a substitute of dolomite when the soil $\mathrm{pH}$ must be kept at certain level safe for heart rot disease.

\section{Acknowledgments}

The authors would like to express their gratitude to the United Graduate School of Agricultural Science (UGSAS), Gifu University, Japan for the support of this research through the Ronpaku Program. Sincere thanks are extended to the Management of PT. Great Giant Pineapple, for permitting, funding and supporting this study. Thanks are also extended to Dewi Puspita Widiarini, my college in R\&D PT. GGP.

\section{Financial Support}

This research was supporting and funding by PT. Great Giant Pineapple, Central Lampung, Indonesia and Ronpaku Program, UGSAS, Gifu University Japan.

\section{Conflicts of Interest}

The authors declare there are no conflicts of interest.

\section{References}


1 Von Uexkull HR and Bossart (1989) Management of acid upland soils in Asia. In Management of Acid Soils in the Humid Tropics of Asia. ACIAR Monograph 13, 2-19.

2 Prasetya BH and Suriadikarta DA (2009) Characteristic, potential, and technology of ultisol soil management for the development of dry land agriculture in Indonesia. Agricultural Research and Development Journal 25, 39-46

3 Malezieux E and Bartholomew DP (2003) Plant Nutrition. In Bartholomew DP, Paul RE, Rohrbach KG (eds) The Pineapple: Botany, Production and Uses. Wallingford, USA: CABI Publishing, pp. 143- 166.

4 Uchida R and Hue NV (2000) Soil acidity and liming. In Silva JA and Uchida R (eds), Plant nutrient management in Hawaii's soils, approaches for tropical and subtropical agriculture, Hawaii: University of Hawaii, pp. 101- 106.

5 Taiz L, Zeiger E and Moller IM (2015) Plant Physiology and Development $6^{\text {th }}$ ed. Massachusetts USA: Sinaur Associates, pp. 1- 623.

6 Tailep Wael MAK, El-Saadani AM, El-Dahshouri MF ande Mohamed F (2019) Influence of foliar spray of different calcium sources on nutritional status, seed yield and quality for some peanut genotypes. Bioscience research 16, 309- 319.

7 Olle M and Bender I (2009) Causes and control of calcium deficiency disorders in vegetables: a review. Jounal of Horticultural Science and Biotechnology 84, 577- 584.

8 Von Uexkull HR (1986) Efficient fertilizer use in acid upland soils of the humid tropics. FAO fertilizer and Plant Nutrition Bulletin 10. FAO. Rome.

9 Rohrbach KG and Johnson MW (2003) Pests, Diseases and Weeds. In Bartholomew DP, Paul RE, Rohrbach KG (eds) The Pineapple: Botany, Production and Uses. Wallingford, USA: CABI Publishing, pp. 203-252.

10 Pegg KG (1993) Diseases. In In R.H. Broadly RH, Wassman III RC and Sinclair E(eds) Pineapple Pest and Disorder. DPI Queensland:11-32.

11 Mite F, Espinosa J, and Medina L (2010) Liming Effect on Pineapple Yield and Soil Properties in Volcanic Soils. Better Crops Vol.94 (1):7-9.

12 Vasquez-Jimenez and Bartholomew DP (2018) 8 Plant Nutrition. In Sanewski GM, Bartholomew DP and Paull RE (eds), The Pineapple: botany, production and uses $2^{\text {nd }}$ ed. London: CABI Publishing, pp. 175- 202.

13 Silva JA, Hamasaki R, Ogoshi R, Bartholomew DP, Fukuda S, Hue NV, Uehara G and Tsuji GY (2006) Lime, gypsum, and basaltic dust effects on the calcium nutrition and fruit quality of pineapple. Acta Horticulturae 702, 123- 131.

14 Pegg K and Giblin F (2008) Principle of Phytophthora root rot management in establish orchards Queensland. Talking Avocados 19, 36-38.

15 Messenger BJ, Menge JA and Pond E (2000) Effect of gypsum on zoospores and sporangia of Phytophthora cinnamomi in field soil. Plant Disease 84, 617- 621.

16 Correia AF, Neves LG, Serafim ME, Zeviani WM, Araujo KL and Marostega TN (2017) Chemical attributes of soil with use of a cover crop and agricultural gypsum in pineapple. Revista de Ciencias Agrarias / Amazonian Journal of Agricultural and Environmental Sciences 60, 25- 32. 
17 Afandi A, Hieno A, Wobowo A, Subandiyah S, Afandi, Suga H, Tsuchida K, and Kageyama K (2019) Genetic diversity of Phytophthora nocotianae reveals pathogen transmission mode in Japan. Journal of General Plant Pathology 85, 189- 200.

18 Tsao PH, Draft GC, Sztejnberg A and Miyata Y (1986) Potting mixes for control Phytophthora root rot. Slosson.ucdavis.edu, pp. 27- 28.

19 Zook MN, Rush JS and Kuc JC (1987) A role for Ca2+ in the elicitation of rishitin and lubimin accumulation in potato tuber tissue. Plant Physiology 84, 520- 525.

20 Liming C and Warren AD (2011) Gypsum as an agricultural amendment, general use guidelines. Bulletin 945, Ohio State University.

21 Kelly DS (1993) Nutritional disorder. In Roger HB, Rudolf CW, and Eric S (eds), Pineapple pest and disorders, Queensland, Australia: Department of Primary Industries, pp 33- 42.

22 Nome C, Magalhaes PC, Oliveira E, Nome S and Laguna LG (2009) Differences in intracellular localization of corn stunt spiroplasmas in magnesium treated maize. Biocell 33, 133- 136.

23 Huber DM and Jones JB (2013) The role of magnesium in plant disease. Plant Soil $368,73-85$.

24 Taiz L and Zeiger E (2002) Plant Physiology, 3 ${ }^{\text {rd }}$ ed. Sinaur Associates, pp. 1- 675.

25 Souza LFS and Reinhardt DH (2007) Pineapple. In Johnson AE (ed) Tropical Fruits of Brazil, Horgen : Bulletin 18 International Potash Intitute, pp. 179- 201.

26 Marschner P (2012) Marschner's mineral nutrition of higher plants, $3^{\text {rd }}$ ed, USA: Academic Press, pp.

27 De Freitas ST and Mitcham EJ (2012) Factor involved in fruit calcium deficiency disorders. Horticultural Reviews 40, 107- 146.

28 Saure M (2014) Why calcium deficiency is not the cause of blossom-end rot in tomato and pepper fruit reappraisal. Scientia Horticulturae 174, 65- 89.

29 Villanueva MJ, Tenorio MD, Esteban MA and Mendosa (2004) Compositional changes during ripening of two cultivars of maskmelon fruits. Foot Chem 87, 179- 183.

30 USDA, 1990. United States Standards for Grades of Canned Pineapple.

31 Lobo MG and Yahia E (2017) Biology and Postharvest Physiology of Pineapple. In Lobo MG and Paull RE (eds) Handbook of Pineapple Technology: Production, Postharvest Science, Processing and Nutrition. John Wiley \& Sons Ltd, pp. 39- 61.

Table 1. Soil analysis at planting

\begin{tabular}{|c|c|c|c|c|c|}
\hline \multirow{2}{*}{ Properties } & \multirow{2}{*}{ Unit } & Experiment 1 & \multicolumn{2}{|c|}{ Experiment 2 } & \multirow{2}{*}{ Fine compost } \\
\cline { 3 - 5 } & & $\begin{array}{c}\text { At planting } \\
\text { (Dec, 2016) }\end{array}$ & $\begin{array}{c}\text { Initial soil } \\
\text { (May, 2017) }\end{array}$ & $\begin{array}{c}\text { At planting } \\
\text { (Sep, 2017) }\end{array}$ & \\
\hline $\mathrm{pH}$ & - & 4.6 & 4.2 & 4.4 & 7.2 \\
$\mathrm{P}$ & $\mathrm{mg} / \mathrm{kg}$ & 17.7 & 21.2 & 22.9 & 2.6 \\
$\mathrm{~K}$ & $\mathrm{mg} / \mathrm{kg}$ & 86.4 & 68.5 & 75.0 & 18.13 \\
\hline
\end{tabular}




\begin{tabular}{|c|c|c|c|c|c|}
\hline $\mathrm{Ca}$ & $\mathrm{mg} / \mathrm{kg}$ & 314.4 & 60.3 & 127.8 & 21.50 \\
$\mathrm{Mg}$ & $\mathrm{mg} / \mathrm{kg}$ & 98.6 & 49.1 & 60.8 & 5.26 \\
$\mathrm{Cu}$ & $\mathrm{mg} / \mathrm{kg}$ & Not analysed & 0.6 & 0.6 & Not analysed \\
Total C & $\mathrm{Wt} \%$ & 1.2 & 1.4 & 1.3 & 21.6 \\
Total N & $\mathrm{Wt} \%$ & Not analysed & Not analysed & Not analysed & 1.68 \\
C/N ratio & - & Not analysed & Not analysed & Not analysed & 12.86 \\
& & & & \\
\hline
\end{tabular}

Note: Liming dolomite 1 ton ha $^{-1}$ was done at June 2017 (Exp. 2)

Table 2. Mortality of pineapple due to Phytophthora nicotianae disease at 4,6,8 and 10 weeks after planting (WAP).

\begin{tabular}{|l|c|c|c|c|}
\hline \multirow{2}{*}{ Treatment } & \multicolumn{4}{|c|}{ Plant mortality (\%) } \\
\cline { 2 - 5 } & $\mathbf{4}$ WAP & $\mathbf{6 ~ W A P}$ & $\mathbf{8}$ WAP & $\mathbf{1 0}$ WAP \\
\hline G0 (Untreated) & $0.0 \mathrm{a}$ & $1.3 \mathrm{a}$ & $2.7 \mathrm{a}$ & $3.3 \mathrm{a}$ \\
G1 (Gypsum 1000 kg/ha) & $0.0 \mathrm{a}$ & $4.7 \mathrm{a}$ & $9.3 \mathrm{a}$ & $10.3 \mathrm{a}$ \\
G2 (Gypsum 1500 kg/ha) & $0.0 \mathrm{a}$ & $4.3 \mathrm{a}$ & $7.0 \mathrm{a}$ & $8.7 \mathrm{a}$ \\
G3 (Gypsum 2000 kg/ha) & $0.3 \mathrm{a}$ & $7.3 \mathrm{ab}$ & $12.0 \mathrm{a}$ & $14.3 \mathrm{a}$ \\
D1 (Dolomite 2000 kg/ha) & $0.7 \mathrm{a}$ & $24.3 \mathrm{~b}$ & $54.3 \mathrm{~b}$ & $63.8 \mathrm{~b}$ \\
\hline P- value & 0.12 & 0.01 & 0.00 & 0.00 \\
\hline
\end{tabular}

Means within a column followed by a common letter are not significantly different $(\mathrm{P}<0.05)$ according to Tuckey test of difference.

Table 3. Soil $\mathrm{pH}, \mathrm{Ca}$ and $\mathrm{Mg}$ contents in soil at 0, 4 and 10 weeks after planting (WAP).

\begin{tabular}{|c|c|c|c|c|c|c|c|c|c|}
\hline \multirow[b]{2}{*}{ Treatment } & \multicolumn{3}{|c|}{ Soil pH } & \multicolumn{3}{|c|}{ Ca (mg/kg) } & \multicolumn{3}{|c|}{ Mg (mg/kg) } \\
\hline & 0 WAP & 4 WAP & $\begin{array}{c}10 \\
\text { WAP }\end{array}$ & $0 \mathrm{WAP}$ & 4 WAP & $\begin{array}{c}10 \\
\text { WAP }\end{array}$ & 0 WAP & 4 WAP & $\begin{array}{c}10 \\
\text { WAP }\end{array}$ \\
\hline G0 & 4.6 & $5.1 \mathrm{a}$ & $4.5 \mathrm{a}$ & 314 & $430 \mathrm{a}$ & $311 \mathrm{a}$ & 99 & $137 \mathrm{ab}$ & $75 a b$ \\
\hline G1 & 4.6 & $5.3 \mathrm{ab}$ & $4.6 \mathrm{a}$ & 314 & $493 \mathrm{a}$ & $379 a b$ & 99 & $156 \mathrm{ab}$ & $77 \mathrm{ac}$ \\
\hline G2 & 4.6 & $5.3 \mathrm{ab}$ & $4.7 \mathrm{a}$ & 314 & 489 a & $400 \mathrm{~b}$ & 99 & 146 a & 98 ac \\
\hline G3 & 4.6 & $5.0 \mathrm{a}$ & $4.7 \mathrm{a}$ & 314 & $448 \mathrm{a}$ & $389 \mathrm{~b}$ & 99 & $120 \mathrm{~b}$ & $62 \mathrm{~b}$ \\
\hline D1 & 4.6 & $5.5 \mathrm{~b}$ & $5.9 \mathrm{~b}$ & 314 & $467 \mathrm{a}$ & $369 a b$ & 99 & $162 \mathrm{c}$ & $159 \mathrm{c}$ \\
\hline P-value & - & 0.00 & 0.00 & - & 0.61 & 0.02 & - & 0.00 & 0.00 \\
\hline
\end{tabular}

Means within a column followed by a common letter are not significantly different $(\mathrm{P}<0.05)$ according to Tuckey test of difference.

Table 4. D-Leaf length and plant weight at 3, 7, 9 and 11 months after planting (MAP)

\begin{tabular}{|l|c|c|c|c|c|c|c|c|}
\hline \multirow{2}{*}{ Treatment } & \multicolumn{4}{|c|}{ D-Leaf length (cm) } & \multicolumn{4}{c|}{ Plant weight (g) } \\
\cline { 2 - 9 } & 3 MAP & 7 MAP & 9 MAP & 11 MAP & 3 MAP & 7 MAP & 9 MAP & 11 MAP \\
\hline G0 (Untreated) & $51.2 \mathrm{a}$ & $75.9 \mathrm{a}$ & $87.2 \mathrm{a}$ & $95.1 \mathrm{a}$ & $201.3 \mathrm{a}$ & $842.5 \mathrm{a}$ & $1336.3 \mathrm{a}$ & $2546.3 \mathrm{a}$ \\
G1 (0.5 ton/ha) & $51.0 \mathrm{a}$ & $75.8 \mathrm{a}$ & $88.1 \mathrm{a}$ & $97.4 \mathrm{a}$ & $215.0 \mathrm{ab}$ & $1032.5 \mathrm{a}$ & $1606.3 \mathrm{ab}$ & $2592.5 \mathrm{a}$ \\
\hline
\end{tabular}




\begin{tabular}{|c|c|c|c|c|c|c|c|c|}
\hline G1 (1.0 ton/ha) & $53.1 \mathrm{a}$ & $77.4 \mathrm{a}$ & $89.4 \mathrm{a}$ & $96.5 \mathrm{a}$ & $222.5 \mathrm{ab}$ & $901.3 \mathrm{ab}$ & $1450.0 \mathrm{ab}$ & $2772.5 \mathrm{a}$ \\
G1 (1.5 ton/ha) & $51.9 \mathrm{a}$ & $76.4 \mathrm{a}$ & $89.0 \mathrm{a}$ & $97.2 \mathrm{a}$ & $207.5 \mathrm{ab}$ & $1021.3 \mathrm{~b}$ & $1736.3 \mathrm{~b}$ & $2598.8 \mathrm{a}$ \\
G1 (2.0 ton/ha) & $53.6 \mathrm{a}$ & $78.1 \mathrm{a}$ & $90.2 \mathrm{a}$ & $104.7 \mathrm{a}$ & $210.0 \mathrm{ab}$ & $1002.5 \mathrm{ab}$ & $1698.8 \mathrm{ab}$ & $2722.5 \mathrm{a}$ \\
G5 (2.5 ton/ha) & $54.1 \mathrm{a}$ & $76.6 \mathrm{a}$ & $88.7 \mathrm{a}$ & $96.2 \mathrm{a}$ & $225.0 \mathrm{~b}$ & $1037.5 \mathrm{~b}$ & $1725.0 \mathrm{ab}$ & $2520.0 \mathrm{a}$ \\
\hline P-value & 0.56 & 0.94 & 0.91 & 0.36 & 0.02 & 0.01 & 0.02 & 0.66 \\
\hline
\end{tabular}

Means within a column followed by a common letter are not significantly different $(\mathrm{P}<0.05)$ according to Tuckey test of difference.

Table 5. Root length, total root number, root fresh and root dry weight at 3 months after planting (MAP).

\begin{tabular}{|l|c|c|c|c|}
\hline Treatment & $\begin{array}{c}\text { Root } \\
\text { length }(\mathbf{c m})\end{array}$ & $\begin{array}{c}\text { Total } \\
\text { root } \\
\text { number }\end{array}$ & $\begin{array}{c}\text { Root } \\
\text { fresh weight (cm) }\end{array}$ & $\begin{array}{c}\text { Root } \\
\text { dry weight (cm) }\end{array}$ \\
\hline G0 (Untreated) & $43.1 \mathrm{a}$ & $38.9 \mathrm{a}$ & $5.3 \mathrm{a}$ & $2.5 \mathrm{a}$ \\
G1 (0.5 ton/ha) & $41.8 \mathrm{a}$ & $29.9 \mathrm{a}$ & $5.8 \mathrm{a}$ & $2.7 \mathrm{a}$ \\
G1 (1.0 ton/ha) & $45.1 \mathrm{a}$ & $35.8 \mathrm{a}$ & $5.3 \mathrm{a}$ & $2.6 \mathrm{a}$ \\
G1 (1.5 ton/ha) & $41.9 \mathrm{a}$ & $32.5 \mathrm{a}$ & $5.3 \mathrm{a}$ & $2.1 \mathrm{a}$ \\
G1 (2.0 ton/ha) & $46.3 \mathrm{a}$ & $34.7 \mathrm{a}$ & $4.5 \mathrm{a}$ & $3.3 \mathrm{a}$ \\
\hline G5 (2.5 ton/ha) & $43.9 \mathrm{a}$ & $36.3 \mathrm{a}$ & $6.5 \mathrm{a}$ & 0.10 \\
\hline
\end{tabular}

Means within a column followed by a common letter are not significantly different $(\mathrm{P}<0.05)$ according to Tuckey test of difference.

Table 6. Plant weight, stem weight, fruit and crown weight at harvest in gram (g)

\begin{tabular}{|l|c|c|c|c|}
\hline Treatment & $\begin{array}{c}\text { Plant weight } \\
\text { at harvest }\end{array}$ & $\begin{array}{c}\text { Stem weight } \\
\text { at harvest }\end{array}$ & $\begin{array}{c}\text { Fruit } \\
\text { weight }\end{array}$ & $\begin{array}{c}\text { Crown } \\
\text { weight }\end{array}$ \\
\hline G0 (Untreated) & $2451.3 \mathrm{a}$ & $520.0 \mathrm{a}$ & $1455.0 \mathrm{a}$ & $322.5 \mathrm{a}$ \\
G1 (0.5 ton/ha) & $2908.3 \mathrm{a}$ & $607.5 \mathrm{a}$ & $1497.5 \mathrm{a}$ & $402.5 \mathrm{a}$ \\
G1 (1.0 ton/ha) & $2730.0 \mathrm{a}$ & $590.0 \mathrm{a}$ & $1731.3 \mathrm{a}$ & $365.0 \mathrm{a}$ \\
G1 (1.5 ton/ha) & $2645.0 \mathrm{a}$ & $580.0 \mathrm{a}$ & $1467.5 \mathrm{a}$ & $330.0 \mathrm{a}$ \\
G1 (2.0 ton/ha) & $2647.5 \mathrm{a}$ & $532.5 \mathrm{a}$ & $1677.5 \mathrm{a}$ & $335.0 \mathrm{a}$ \\
G5 (2.5 ton/ha) & $2527.3 \mathrm{a}$ & $537.5 \mathrm{a}$ & $1632.5 \mathrm{a}$ & $345.0 \mathrm{a}$ \\
\hline P-value & 0.41 & 0.59 & 0.13 & 0.51 \\
\hline
\end{tabular}

Means within a column followed by a common letter are not significantly different $(\mathrm{P}<0.05)$ according to Tuckey test of difference.

Table 7. Pineapple fruits quality at harvest

\begin{tabular}{|c|c|c|c|c|c|c|c|c|c|}
\hline \multirow{3}{*}{ Treatment } & \multirow{3}{*}{$\begin{array}{l}\text { Fruit } \\
\text { TSS } \\
\text { ('Brix) }\end{array}$} & \multirow{3}{*}{$\begin{array}{c}\text { Fruit } \\
\text { TA } \\
(\%)\end{array}$} & \multirow{3}{*}{$\begin{array}{l}\text { TSS/ } \\
\text { TA } \\
\text { ratio }\end{array}$} & \multicolumn{6}{|c|}{ Fruit texture (firmness) } \\
\hline & & & & \multicolumn{3}{|c|}{$\begin{array}{l}\text { Shell colour } 1 \\
(10 \% \text { yellow })\end{array}$} & \multicolumn{3}{|c|}{$\begin{array}{c}\text { Shell colour } 3 \\
(20-30 \% \text { yellow })\end{array}$} \\
\hline & & & & Top & Middle & Bottom & Top & Middle & Bottom \\
\hline
\end{tabular}




\begin{tabular}{|l|c|c|c|c|c|c|c|c|c|}
\hline & & & & $(\mathbf{g})$ & $\mathbf{( g )}$ & $\mathbf{( g )}$ & $\mathbf{( g )}$ & $\mathbf{( g )}$ & $\mathbf{( g )}$ \\
\hline G0 (Untreated) & $13.5 \mathrm{a}$ & $0.55 \mathrm{a}$ & 24.5 & $282.8 \mathrm{a}$ & $282.2 \mathrm{a}$ & $278.3 \mathrm{a}$ & $230.6 \mathrm{a}$ & $261.7 \mathrm{a}$ & $230.6 \mathrm{a}$ \\
G1 (0.5 ton/ha) & $12.6 \mathrm{a}$ & $0.49 \mathrm{a}$ & 25.6 & $296.7 \mathrm{a}$ & $298.3 \mathrm{a}$ & $282.2 \mathrm{a}$ & $267.2 \mathrm{a}$ & $267.2 \mathrm{a}$ & $267.2 \mathrm{a}$ \\
G1 (1.0 ton/ha) & $12.1 \mathrm{ab}$ & $0.46 \mathrm{a}$ & 26.2 & $283.3 \mathrm{a}$ & $289.4 \mathrm{a}$ & $281.7 \mathrm{a}$ & $257.8 \mathrm{a}$ & $277.2 \mathrm{a}$ & $257.8 \mathrm{a}$ \\
G1 (1.5 ton/ha) & $12.7 \mathrm{a}$ & $0.53 \mathrm{a}$ & 23.9 & $326.1 \mathrm{a}$ & $312.8 \mathrm{a}$ & $282.2 \mathrm{a}$ & $262.8 \mathrm{a}$ & $279.4 \mathrm{a}$ & $262.8 \mathrm{a}$ \\
G1 (2.0 ton/ha) & $12.0 \mathrm{ab}$ & $0.50 \mathrm{a}$ & 23.9 & $281.1 \mathrm{a}$ & $289.4 \mathrm{a}$ & $299.4 \mathrm{a}$ & $254.4 \mathrm{a}$ & $267.8 \mathrm{a}$ & $254.4 \mathrm{a}$ \\
G5 (2.5 ton/ha) & $13.3 \mathrm{a}$ & $0.52 \mathrm{a}$ & 25.6 & $285.6 \mathrm{a}$ & $292.2 \mathrm{a}$ & $303.3 \mathrm{a}$ & $293.9 \mathrm{a}$ & $275.6 \mathrm{a}$ & $293.9 \mathrm{a}$ \\
\hline P-value & 0.045 & 0.140 & - & 0.916 & 0.720 & 0.844 & 0.431 & 0.977 & 0.121 \\
\hline
\end{tabular}

Means within a column followed by a common letter are not significantly different $(\mathrm{P}<0.05)$ according to Tuckey test of difference.

Table 8. Fruit size distribution at harvest

\begin{tabular}{|c|c|c|c|c|c|c|}
\hline \multirow{2}{*}{ Treatment } & \multicolumn{7}{|c|}{ Fruit size distribution (\%) } \\
\cline { 2 - 7 } & $<\mathbf{1 T}$ & $\mathbf{1 ~ T}$ & $\mathbf{1 3 / 8} \mathbf{~ T}$ & $\mathbf{2 ~ T}$ & $\mathbf{2 ~ 1 / 2 ~ T}$ & $\mathbf{( 2 ~ T ~ + ~ 2 ~ 1 / 2 ~ T ) ~}$ \\
\hline G0 (Untreated) & $3.7 \mathrm{a}$ & $12.0 \mathrm{a}$ & $15.4 \mathrm{a}$ & $26.0 \mathrm{a}$ & $43.0 \mathrm{a}$ & 68.9 \\
G1 (0.5 ton/ha) & $3.0 \mathrm{a}$ & $8.2 \mathrm{a}$ & $10.7 \mathrm{a}$ & $31.2 \mathrm{a}$ & $46.8 \mathrm{a}$ & 78.0 \\
G1 (1.0 ton/ha) & $2.8 \mathrm{a}$ & $8.0 \mathrm{a}$ & $15.6 \mathrm{a}$ & $33.1 \mathrm{a}$ & $40.5 \mathrm{a}$ & 73.6 \\
G1 (1.5 ton/ha) & $2.2 \mathrm{a}$ & $8.2 \mathrm{a}$ & $15.1 \mathrm{a}$ & $28.5 \mathrm{a}$ & $46.1 \mathrm{a}$ & 74.5 \\
G1 (2.0 ton/ha) & $4.5 \mathrm{a}$ & $8.4 \mathrm{a}$ & $13.1 \mathrm{a}$ & $30.8 \mathrm{a}$ & $43.1 \mathrm{a}$ & 73.9 \\
G5 (2.5 ton/ha) & $1.7 \mathrm{a}$ & $11.4 \mathrm{a}$ & $14.8 \mathrm{a}$ & $30.7 \mathrm{a}$ & $41.4 \mathrm{a}$ & 72.1 \\
\hline P-value & 0.601 & 0.771 & 0.707 & 0.863 & 0.588 & - \\
\hline
\end{tabular}

Means within a column followed by a common letter are not significantly different $(\mathrm{P}<0.05)$ according to Tuckey test of difference.

Table 9. Crown size distribution at harvest

\begin{tabular}{|c|c|c|c|c|c|c|}
\hline \multirow{2}{*}{ Treatment } & \multicolumn{7}{|c|}{ Crown size distribution (\%) } \\
\cline { 2 - 7 } & $\begin{array}{c}\text { Extra } \\
\text { small }\end{array}$ & Small & Medium & Big & Extra big & (Big + Extra big) \\
\hline G0 (Untreated) & $0.3 \mathrm{a}$ & $3.2 \mathrm{a}$ & $60.1 \mathrm{a}$ & $33.2 \mathrm{a}$ & $3.2 \mathrm{a}$ & 36.4 \\
G1 (0.5 ton/ha) & $0.0 \mathrm{a}$ & $0.0 \mathrm{a}$ & $40.1 \mathrm{a}$ & $54.2 \mathrm{a}$ & $5.7 \mathrm{a}$ & 59.9 \\
G1 (1.0 ton/ha) & $0.0 \mathrm{a}$ & $3.0 \mathrm{a}$ & $39.3 \mathrm{a}$ & $54.0 \mathrm{a}$ & $3.7 \mathrm{a}$ & 57.7 \\
G1 (1.5 ton/ha) & $0.0 \mathrm{a}$ & $1.7 \mathrm{a}$ & $43.9 \mathrm{a}$ & $52.6 \mathrm{a}$ & $1.8 \mathrm{a}$ & 54.4 \\
G1 (2.0 ton/ha) & $0.0 \mathrm{a}$ & $3.3 \mathrm{a}$ & $40.8 \mathrm{a}$ & $54.4 \mathrm{a}$ & $1.5 \mathrm{a}$ & 56.9 \\
\hline
\end{tabular}




\begin{tabular}{|c|c|c|c|c|c|c|}
\hline G5 (2.5 ton/ha) & $0.0 \mathrm{a}$ & $3.7 \mathrm{a}$ & $35.0 \mathrm{a}$ & $56.0 \mathrm{a}$ & $5.7 \mathrm{a}$ & 61.7 \\
\hline P-value & 0.458 & 0.895 & 0.433 & 0.346 & 0.691 & - \\
\hline
\end{tabular}

Means within a column followed by a common letter are not significantly different $(\mathrm{P}<0.05)$ according to Tuckey test of difference.

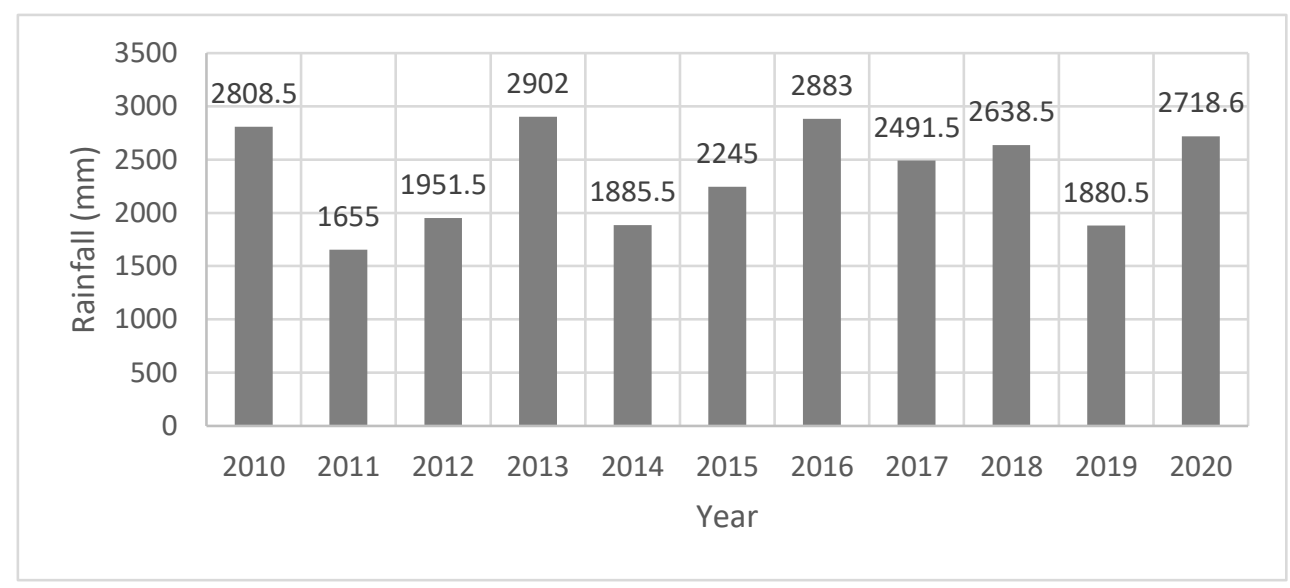

Figure 1. Yearly rainfall with several "wet dry season" and "long dry season" normal rainfall was around $2500 \mathrm{~mm} / \mathrm{year}$

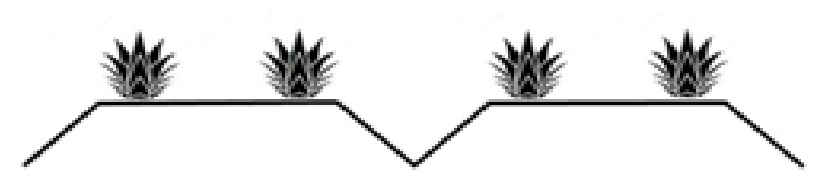

Figure 2. Raised bed double row

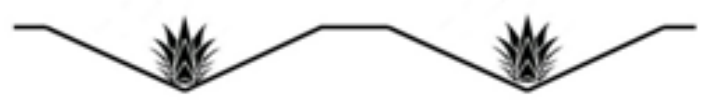

Figure 3. Lower bed single row 


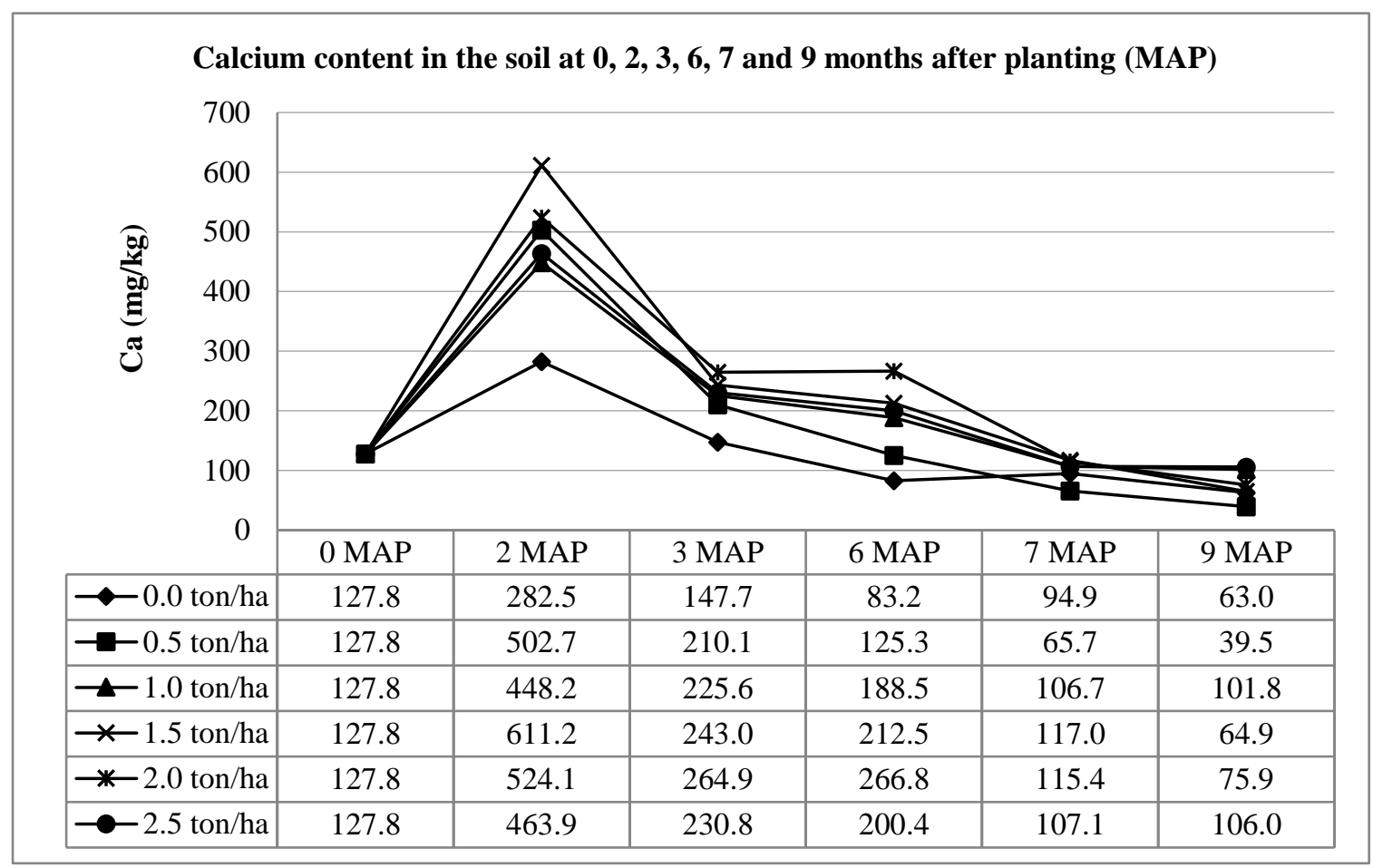

Figure 4. Calcium content in the soil at 0, 2, 3, 6, 7 and 9 months after planting (map).

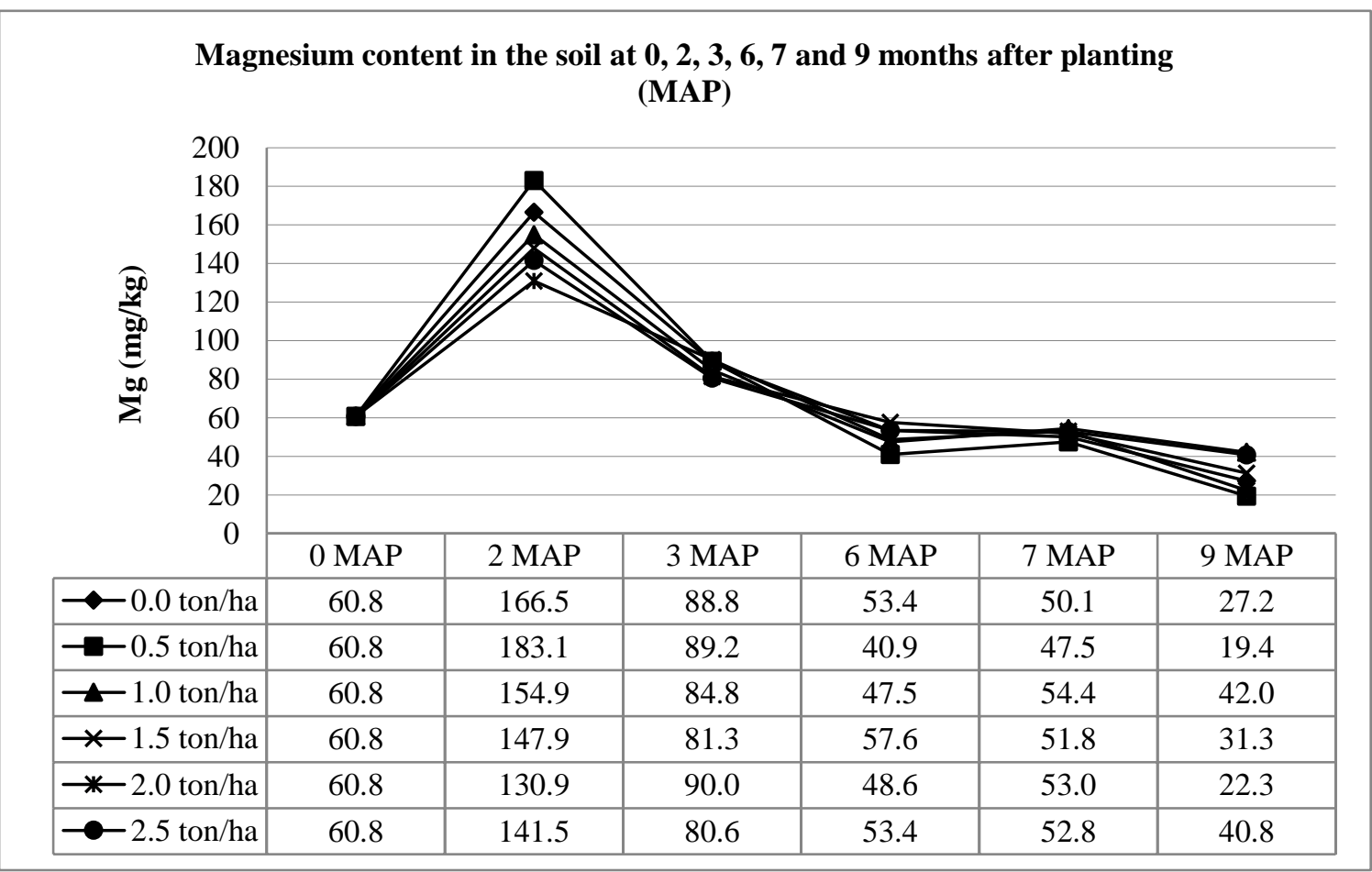

Figure 5. Magnesium content in the soil at $0,2,3,6,7$ and 9 months after planting 


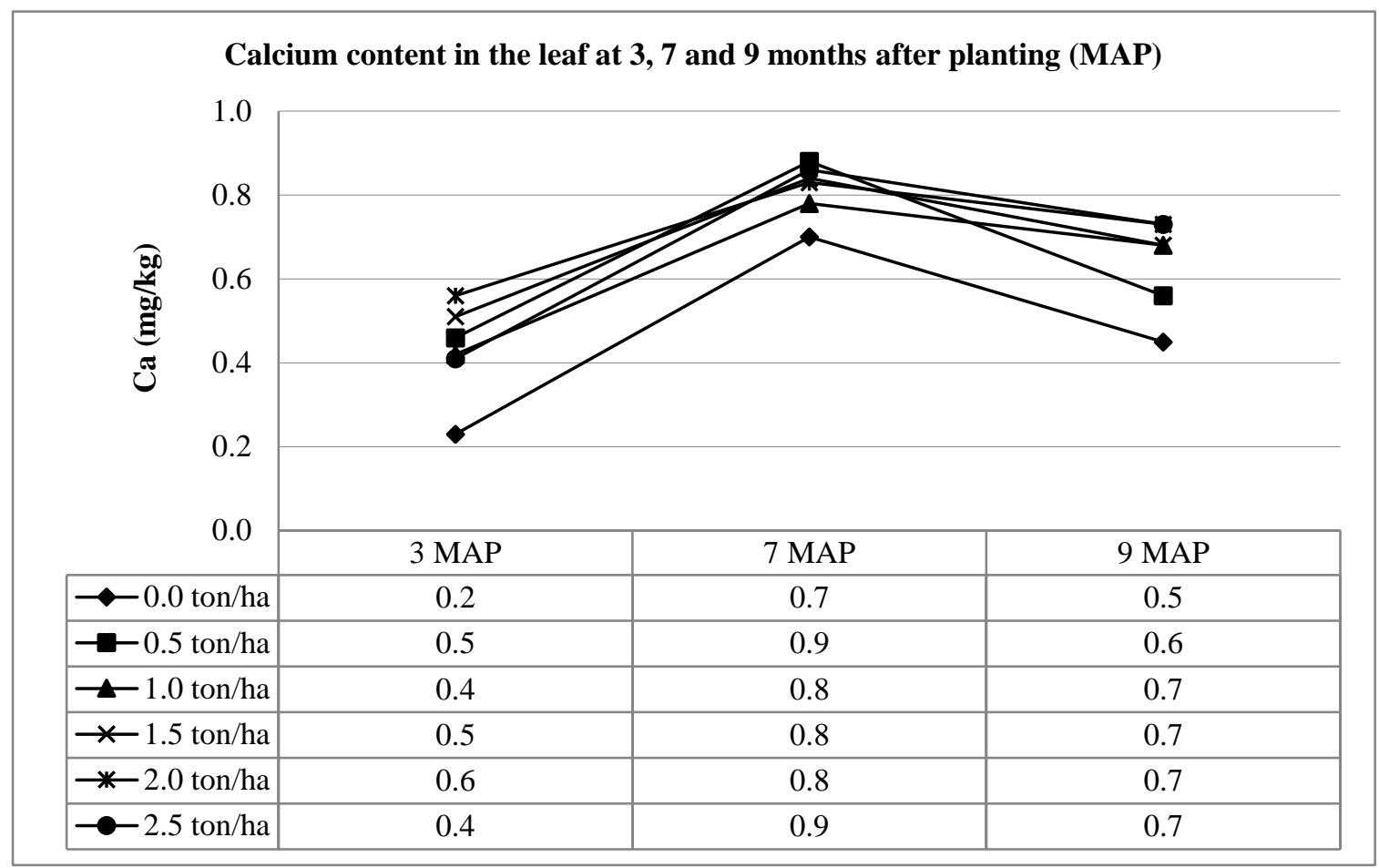

Figure 6. Calsium content in the leaf at 3, 7 and 9 months after planting.

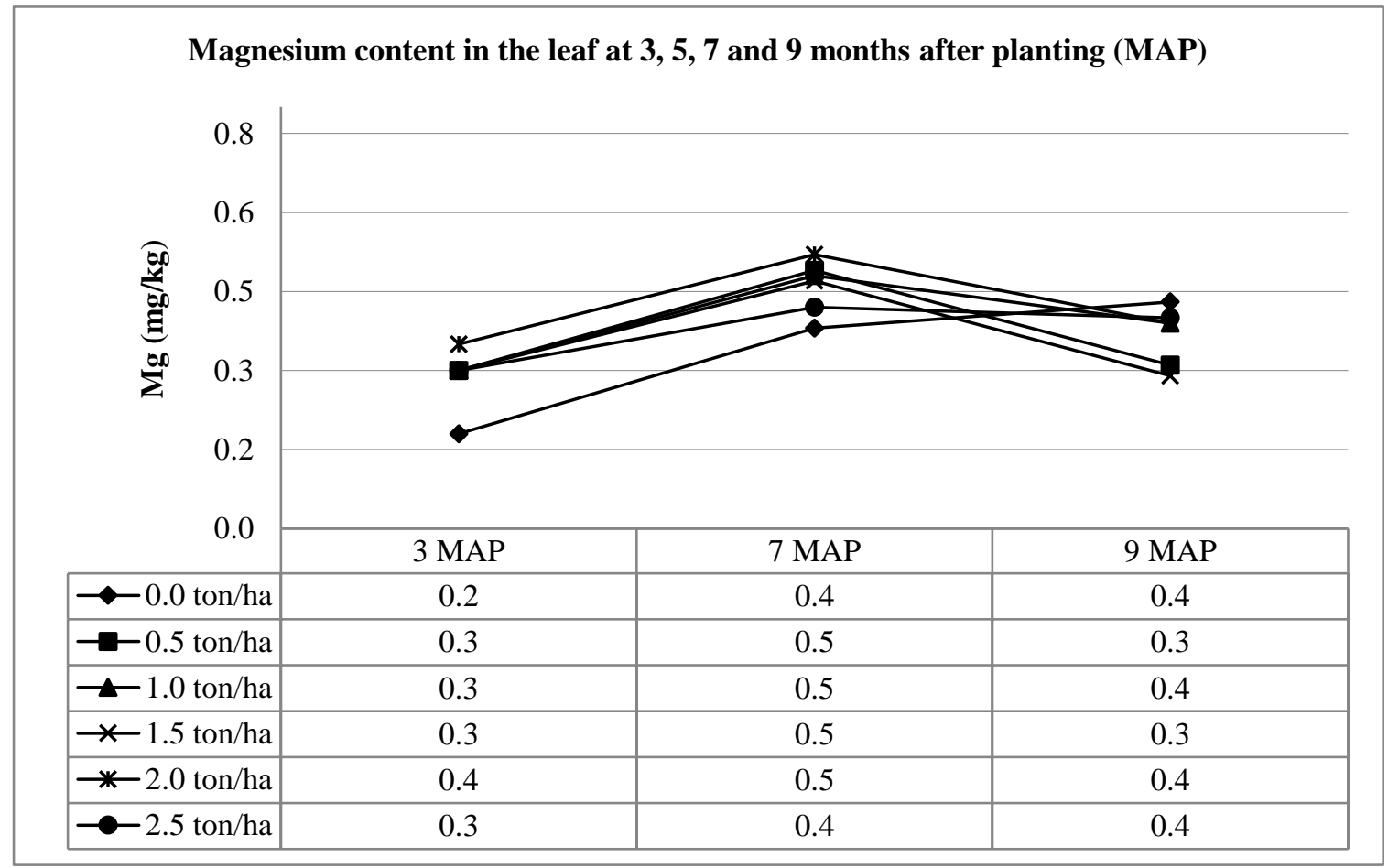

Figure 7. Magnesium content in the leaf at 3, 7 and 9 months after planting. 